\title{
EFEKTIVITAS PENILAIAN KINERJA BERBASIS E-KINERJA DI PUSAT PELATIHAN MANAJEMEN DAN KEPEMIMPINAN PERTANIAN
}

\author{
EFFECTIVENESS OF PERFORMANCE ASSESSMENT \\ BASED ON E-PERFORMANCE IN CENTRE OF AGRICULTURAL \\ MANAGEMENT AND LEADERSHIP TRAINING
}

\author{
Indra Rukmana ${ }^{*}$, Rita Rahmawati², Euis Salbiah ${ }^{3}$ \\ 1,2,3Program Studi Administrasi Publik, Fakultas Ilmu Sosial dan Ilmu Politik, Universitas \\ Djuanda, Jl. Tol Ciawi No. 1, Kotak Pos 35, Bogor 16720 \\ *Korespondensi: Indra Rukmana. Email: ind.rkmn@gmail.com
}

(Diterima: 11-03-2020; Ditelaah: 16-03-2020; Disetujui: 24-03-2020)

\begin{abstract}
The performance assessment plays a key role for an organization because of allowing it to know, measure and evaluate the performance of its members. The result of performance assessment helps an organization to take a decision in managing the human resources of organization. The performance assessment mostly influences the job effectiveness of the members of organization. The purpose of this research is to describe the effectiveness of performance assessment based on e-performance in Centre of Agricultural Management and Leadership Training. The performance assessment is defined as an assessment on the achievement or the working ability shown by the civil servant in carrying out the task and function suitable to the working target, namely the number of work load achieved from the implementation of the job. The performance of civil servant can be assessed his/her working effectiveness based on four dimensions, namely quantity, quality, time and cost. Method of this research is descriptive. Samples of this research consist of 61 civil servants taken as respondents of this research. This research uses questionaires as main instrument to collect data. Data are analyzed qualitatively and supported by calculating the mean score. Results of this research indicate that the effectiveness of performance assessment based on e-performance in Centre of Agricultural Management and Leadership Training gets the mean score 4.14 perceived as good. In relation to the four dimensions, the highest score is on the dimension of quality getting the mean score 4.24 perceived as very good, whereas the dimension of cost gets the lowest score 4.06 although perceived as good.
\end{abstract}

Key words: Civil Servant Performance, Effectiveness, E-Performance, Performance Assessment.

\begin{abstract}
ABSTRAK
Penilaian kinerja memegang peranan penting bagi organisasi karena memungkinkan organisasi untuk mengetahui, mengukur dan menilai kinerja pegawai. Hasil penilaian kinerja membantu organisasi untuk mengambil keputusan dalam pengelolaan sumber daya manusia organisasi. Penilaian kinerja sangat berpengaruh terhadap efektivitas kerja pegawai. Tujuan dari penelitian ini adalah untuk mengetahui efektivitas penilaian kinerja berbasis e-kinerja di Pusat Pelatihan Manajemen dan Kepemimpinan Pertanian. Penilaian kinerja dipandang sebagai penilaian atas prestasi/kemampuan kerja yang ditunjukkan oleh pegawai dalam melaksanakan tugas dan fungsinya sesuai dengan target kerja, yaitu jumlah beban kerja yang dicapai dari setiap pelaksanaan tugas jabatan. Kinerja pegawai tersebut dinilai efektivitasnya berdasarkan empat dimensi, yaitu kuantitas, kualitas, waktu dan biaya. Metode yang digunakan dalam penelitian ini adalah metode penelitian deskriptif. Sampel penelitian sebanyak 61 dijadikan sebagai responden penelitian. Penelitian ini menggunakan kuesioner/angket sebagai instrumen utama dalam pengumpulan data. Pengolahan data dilakukan secara kualitatif dengan dibantu melalui penghitungan skor rerata. Hasil penelitian menunjukkan bahwa efektivitas penilaian kinerja berbasis e-kinerja di Pusat Pelatihan Manajemen dan Kepemimpinan Pertanian memperoleh skor rerata sebesar 4,14 termasuk kategori penilaian baik. Dikaitkan dengan empat dimensi penilaian kinerja, maka skor tertinggi berada pada dimensi kualitas yang memperoleh skor rerata sebesar 4,24 termasuk dalam kategori penilaian sangat baik, sedangkan dimensi biaya memiliki skor rerata terendah sebesar 4,06 walaupun termasuk kategori penilaian baik.
\end{abstract}

Kata kunci: Kinerja Pegawai, Efektivitas, E-Kinerja, Penilaian Kinerja.

Rukmana, Indra, Rahmawati, Rita \& Salbiah, Euis. (2020). Efektivitas Penilaian Kinerja Berbasis E-Kinerja di Pusat Pelatihan Manajemen dan Kepemimpinan Pertanian. Jurnal GOVERNANSI, 6(1): 51-56. 


\section{PENDAHULUAN}

Kinerja pegawai berkaitan erat dengan penilaian kinerja, penilaian kinerja diperlukan untuk mengetahui hasil atau tingkat keberhasilan dari pegawai di suatu organisasi. Hasil dari penilaian kinerja dapat digunakan untuk tujuan pengambilan keputusan sumber daya manusia, evaluasi dan umpan balik. Tujuan penilaian kinerja yang paling mendasar adalah untuk meningkatkan kinerja pegawai secara individu sehingga menyebabkan peningkatan kinerja organisasi secara keseluruhan.

Penilaian kinerja, menurut Mondy (2008), merupakan sistem formal untuk meninjau dan mengevaluasi kinerja para individu atau tim dalam menjalankan tugas. Penilaian prestasi kerja/kinerja pegawai negeri sipil berdasarkan Undang-Undang Nomor 43 Tahun 1999, Pasal 12 ayat (2), bertujuan untuk menjamin obyektivitas pembinaan pegawai negeri sipil yang dilakukan berdasarkan sistem prestasi kerja dan sistem karir yang dititikberatkan pada sistem prestasi kerja.

Dalam mewujudkan pembinaan bagi pegawai negeri sipil tersebut, berdasarkan sistem prestasi kerja dan sistem karier yang dititikberatkan pada sistem prestasi kerja, perlu dilakukan penilaian prestasi kerja terhadap pegawai negeri sipil, sebagaimana diatur dalam Peraturan Pemerintah Nomor 46 Tahun 2011 tentang Penilaian Prestasi Kerja Pegawai Negeri Sipil. Penilaian prestasi kerja pegawai negeri sipil, sebagaimana dimaksud dalam Peraturan Pemerintah Nomor 46 Tahun 2011, Pasal 1 angka 2, merupakan suatu proses penilaian secara sistematis yang dilakukan oleh pejabat penilai, yang merupakan pimpinan/atasan langsung pegawai negeri sipil bersangkutan terhadap sasaran kerja pegawai dan perilaku kerja pegawai negeri sipil.

Penilaian prestasi kerja/kinerja pegawai negeri sipil dapat dilakukan melalui ekinerja. Menurut Komara (2014), e-kinerja merupakan salah satu aplikasi berbasis web untuk menganalisis kebutuhan jabatan, beban kerja jabatan dan beban kerja unit atau satuan kerja organisasi sebagai dasar perhitungan prestasi kerja dan pemberian insentif kerja. Dalam konteks ini, Pusat Pelatihan Manajemen dan Kepemimpinan Pertanian sebagai salah satu unit kerja di Kementerian Pertanian mengadopsi dan menerapkan penilaian prestasi kerja/ kinerja pegawai negeri sipil melalui ekinerja.

Dalam menerapkan e-kinerja tersebut, setiap pegawai negeri sipil wajib melaporkan aktivitas harian di aplikasi e-kinerja dengan cara mengunggah aktivitas harian sesuai dengan tugas jabatan masing-masing pegawai. Penilaian kinerja pegawai negeri sipil yang dilakukan di Pusat Pelatihan Manajemen dan Kepemimpinan Pertanian dilaksanakan secara online, sebagaimana diatur di dalam Intruksi Presiden Nomor 3 Tahun 2003 tentang Kebijakan dan Strategi Nasional Pengembangan e-Government.

Penilaian kinerja pegawai negeri sipil berdasarkan Peraturan Menteri Pertanian Republik Indonesia Nomor 12 Tahun 2019 meliputi aspek kuantitas, kualitas, waktu dan biaya. Penilaian kinerja pegawai negeri sipil merupakan penilaian hasil kerja nyata dengan standar kuantitas, kualitas, waktu dan biaya yang dihasilkan oleh setiap pegawai. Penilaian kinerja pegawai negeri sipil wajib dilakukan untuk mengetahui prestasi yang dapat dicapai setiap pegawai, yaitu apakah prestasi kerja yang dicapai setiap pegawai baik, sedang, atau kurang. Penilaian prestasi kerja penting bagi setiap pegawai dan berguna bagi organisasi untuk mengambil keputusan dan menetapkan tindakan kebijakan selanjutnya. Penilaian kinerja merupakan salah satu aspek penting bagi pengelolaan pegawai dalam organisasi, termasuk Pusat Pelatihan Manajemen dan Kepemimpinan Pertanian.

Berdasarkan latar belakang tersebut, maka penelitian ini bertujuan untuk mengetahui dan menggambarkan efektivitas penilaian kinerja berbasis e-kinerja di Pusat Pelatihan Manajemen dan Kepemimpinan Pertanian. 


\section{MATERI DAN METODE}

\section{Konsep/Teori yang Relevan}

Penilaian kinerja merupakan penilaian atas prestasi/kemampuan kerja yang diperlihatkan oleh seorang pegawai dalam melaksanakan tugas dan fungsinya sesuai dengan target kerja, yaitu jumlah beban kerja yang dicapai dari setiap pelaksanaan tugas jabatan. Target kerja memuat aspek kuantitas, kualitas, waktu dan biaya (Peraturan Menteri Pertanian Nomor 12 Tahun 2019).

Penilaian kinerja berbasis e-kinerja menurut Peraturan Menteri Pertanian Nomor 12 Tahun 2019 dilakukan berdasarkan empat dimensi sebagai berikut:

Pertama: Kuantitas. Kuantitas merupakan target dan jumlah hasil kerja yang diperoleh dari kegiatan tugas jabatan, satuan yang digunakan tergantung pada hasil kerja atau aktivitas kerja yang dilakukan.

Kedua: Kualitas. Kualitas merupakan target mutu dari hasil kerja atau aktivitas kerja yang dilakukan dari kegiatan tugas jabatan. Hasil kerja dapat diukur dari kualitas barang/dokumen, tingkat ketepatan waktu atau sasaran atau kualitas proses pekerjaan sesuai dengan kriteria penilaian aspek kualitas.

Ketiga: Waktu. Waktu merupakan target waktu penyelesaian pekerjaan selesai secara tuntas, satuan yang digunakan dalam target waktu berupa bulanan.

Keempat: Biaya. Biaya merupakan target dari anggaran atau penerimaan yang menjadi beban atau target penerimaan dalam Anggaran Pendapatan dan Belanja Negara (APBN) dan sesuai dengan jumlah anggaran belanja atau target penerimaan yang ada dalam APBN.

\section{Metode}

Metode penelitian, menurut Sugiyono (2000), pada hakekatnya merupakan cara untuk mendapatkan data dengan tujuan dari kegunaan tertentu. Penelitian ini menggunakan metode penelitian deskriptif yang bertujuan untuk mengetahui nilai variabel mandiri. Dalam penelitian ini, variabel dimaksud adalah efektivitas penilaian kinerja.

Populasi penelitian mencakup seluruh pegawai di Pusat Pelatihan Manajemen dan Kepemimpinan Pertanian. Penentuan sampel penelitian menggunakan tingkat kesalahan $10 \%$ atau tingkat kepercayaan terhadap populasi sebesar 90\%. Jumlah populasi seluruhnya sebanyak 154 pegawai, dengan menggunakan rumus taro Yamane, maka sampel yang didapatkan berjumlah 61 pegawai, sekaligus dijadikan sebagai responden penelitian.

Data yang dibutuhkan penelitian ini mencakup data primer dan data sekunder. Penelitian ini menggunakan kuesioner/ angket sebagai instrumen utama dalam pengumpulan data primer, di samping pengumpulan data primer juga dilakukan dengan cara wawancara. Data sekunder dikumpulkan dengan cara penelitian kepustakaan.

Kuesioner/angket disusun dengan menggunakan skala Likert untuk mendapatkan data yang bersifat ordinal. Menurut Sugiono (2000), skala Likert digunakan untuk mengukur perilaku, pendapat dan persepsi seseorang atau sekelompok orang tentang fenomena tertentu, dalam penelitian ini tentang efektivitas penilaian kinerja. Jawaban (pendapat dan persepsi) responden terhadap kuesioner/angket tersebut diberi skor (Tabel 1).

Tabel 1. Jawaban Responden dan Skor

\begin{tabular}{lc}
\hline Jawaban & Skor \\
\hline Sangat Baik & 5 \\
\hline Baik & 4 \\
\hline Cukup & 3 \\
\hline Tidak Baik & 2 \\
\hline Sangat Tidak Baik & 1 \\
\hline
\end{tabular}

Jawaban responden terhadap kuesioner/angket dihitung skor rerata (mean) untuk kemudian dilakukan interpretasi dengan kategori penilaian (Tabel 2). 
Tabel 2. Skor Rerata dan Kategori Penilaian

\begin{tabular}{cc}
\hline Skor Rerata & Kategori Penilaian \\
\hline $4,21-5,00$ & Sangat Baik \\
\hline $3,41-4,20$ & Baik \\
\hline $2,61-3,40$ & Cukup Baik \\
\hline $1,81-2,60$ & Kurang Baik \\
\hline $1,00-1,80$ & Tidak Baik \\
\hline
\end{tabular}

\section{HASIL DAN PEMBAHASAN}

Penelitian tentang efektivitas penilaian kinerja berbasis e-kinerja di Pusat Pelatihan Manajemen dan Kepemimpinan Pertanian bertolak dari pemahaman bahwa penilaian kinerja dipandang sebagai suatu proses penilaian secara sistematis yang dilakukan oleh pejabat penilai terhadap sasaran dan perilaku kerja pegawai negeri sipil di Pusat Pelatihan Manajemen dan Kepemimpinan Pertanian.

Penelitian ini dilakukan terhadap penilaian kinerja sebagai penilaian atas prestasi/kemampuan kerja yang ditunjukkan oleh pegawai negeri sipil dalam melaksanakan tugas dan fungsi sesuai dengan target kerja. Penelitian ini mengukur penilaian kinerja pegawai negeri sipil berdasarkan empat dimensi, yaitu kuantitas, kualitas, waktu dan biaya.

Tabel 3. Rekapitulasi Dimensi Kuantitas

\begin{tabular}{llcc}
\hline No. & Item Pernyataan & Rerata & $\begin{array}{c}\text { Kategori } \\
\text { Penilaian }\end{array}$ \\
\hline 1 & $\begin{array}{l}\text { Pekerjaan yang } \\
\text { praktis dan efektif }\end{array}$ & 4,21 & Baik \\
\hline 2 & $\begin{array}{l}\text { Kuantitas kerja } \\
\text { sesuai yang } \\
\text { diharapkan }\end{array}$ & 3,98 & Baik \\
\hline Jumlah & 4,10 & Baik \\
\hline
\end{tabular}

Berdasarkan Tabel 3 hasil rekapitulasi dimensi kuantitas terdapat dua indikator, responden mengatakan dimensi kuantitas mendapatkan kategori penilaian baik dengan skor rerata 4,10. Hal ini menunjukkan bahwa pegawai mampu menghasilkan pekerjaan yang praktis dan efektif sehingga hasil yang didapat akan sesuai target yang sudah ditentukan dan diharapkan oleh organisasi. Kuantitas kerja yang dihasilkan dilihat dari target yang dicapai dari kegiatan tugas jabatan berdasarkan butir kegiatan dan jumlah capaian target tergantung pada tugas pokok yang dibebankan kepada setiap pegawai.

Tabel 4. Rekapitulasi Dimensi Kualitas

\begin{tabular}{llcc}
\hline No. & Item Pernyataan & Rerata & $\begin{array}{c}\text { Kategori } \\
\text { Penilaian }\end{array}$ \\
\hline 1 & $\begin{array}{l}\text { Penilaian kinerja } \\
\text { berdasarkan } \\
\text { standar kerja }\end{array}$ & 4,31 & Sangat Baik \\
\hline 2 & $\begin{array}{l}\text { Kecermatan dan } \\
\text { penelitian dalam } \\
\text { melakukan } \\
\text { penilaian kinerja }\end{array}$ & 4,16 & Baik \\
& & \\
\hline Jumlah & 4,24 & Sangat Baik \\
\hline
\end{tabular}

Berdasarkan hasil Tabel 4 rekapitulasi dimensi kualitas diketahui untuk penilaian hasil kerja 4,24 sudah dikatakan sangat baik, karena pejabat melihat hasil kerja pegawai berdasarkan target kerja pegawai sesuai dengan tugas jabatannya. Dalam hal kecermatan dan ketelitian pejabat penilai diperoleh nilai yang sangat baik dari pegawai karena pejabat penilai memberikan penilaian berdasarkan kesesuaian antara aktivitas harian dengan tugas jabatan.

Tabel 5. Rekapitulasi Dimensi Waktu

\begin{tabular}{llcc}
\hline No. & Item Pernyataan & Rerata & $\begin{array}{c}\text { Kategori } \\
\text { Penilaian }\end{array}$ \\
\hline 1 & $\begin{array}{l}\text { Penilaian kinerja } \\
\text { memperhitungkan } \\
\text { target waktu }\end{array}$ & 4,14 & Baik \\
& & \\
\hline Jumlah & 4,14 & Baik \\
\hline
\end{tabular}

Berdasarkan hasil Tabel 5 rekapitulasi dimensi waktu diperoleh skor rerata 4,14 dengan kategori penilaian baik. Hal ini menunjukkan bahwa penyelesaian pekerjaan sesuai target waktu yang telah ditentukan. Satuan yang digunakan dalam target waktu adalah target bulanan yang dilihat dari aktivitas harian yang diinput ke dalam aplikasi e-kinerja. Dalam hal ini, penyelesaian pekerjaan pegawai, apabila tidak dapat memenuhi target waktu yang sudah ditentukan atau melebihi waktu yang sudah ditetapkan, tentunya berpengaruh terhadap capaian kinerja dari pegawai tersebut. Konsekuensinya adalah bahwa pegawai yang bersangkutan dikatakan pegawai tidak mampu bekerja sesuai dengan target waktu yang telah ditentukan. 
Tabel 6. Rekapitulasi Dimensi Biaya

\begin{tabular}{llcc}
\hline No. & Item Pernyataan & Rerata & $\begin{array}{c}\text { Kategori } \\
\text { Penilaian }\end{array}$ \\
\hline 1 & $\begin{array}{l}\text { Penilaian kinerja } \\
\text { memperhitungkan } \\
\text { pelaksanaan } \\
\text { kegiatan sesuai } \\
\text { dengan target biaya }\end{array}$ & 4,06 & Baik \\
& & \\
\hline Jumlah & 4,06 & Baik \\
\hline
\end{tabular}

Berdasarkan hasil Tabel 6 rekapitulasi dimensi biaya diperoleh skor rerata 4,06 dengan kategori penilaian baik. Hal ini menunjukkan bahwa setiap kegiatan dilaksanakan sesuai dengan target biaya, dimana biaya sesuai dengan jumlah anggaran belanja atau target penerimaan yang sudah ditetapkan dalam Anggaran Pendapatan dan Belanja Negara.

Tabel 7. Hasil Rekapitulasi

Variabel Penilaian Kinerja

\begin{tabular}{lcc}
\hline Dimensi & Rerata & Kategori Penilaian \\
\hline Kuantitas & 4,10 & Baik \\
\hline Kualitas & 4,24 & Sangat Baik \\
\hline Waktu & 4,14 & Baik \\
\hline Biaya & 4,06 & Baik \\
\hline Jumlah & 4,14 & Baik \\
\hline
\end{tabular}

Pada Tabel 7, rekapitulasi penilaian kinerja di Pusat Pelatihan Manajemen dan Kepemimpinan Pertanian menunjukkan skor rerata keseluruhan dimensi sebesar 4,14 yang dikategorikan bernilai baik. Indikator yang mendapat nilai tertinggi sebesar 4,31 adalah indikator target hasil kerja yang menunjukkan bahwa penilaian kinerja sudah sesuai dengan target kerja yang ditentukan oleh organisasi. Penilaian kinerja menunjukkan kategori yang baik sesuai dengan target yang dicapai. Penilaian kinerja pegawai negeri sipil di Pusat Pelatihan Manajemen dan Kepemimpinan Pertanian sudah diterapkan melalui sistem aplikasi e-kinerja sehingga membuat penilaian kinerja sudah berjalan dengan baik dan obyektif.

Efektivitas penilaian kinerja di Pusat Pelatihan Manajemen dan Kepemimpinan Pertanian berpengaruh terhadap kualitas kerja pegawai karena hal tersebut dapat menumbuhkan kinerja pegawai yang lebih produktif sehingga target kerja yang ingin dicapai dapat direalisasikan. Kuantitas kerja juga mampu memberikan hasil yang baik bagi organasasi, dengan jumlah kerja yang dihasilkan seorang pegawai tentunya memberikan dampak yang positif bagi pegawai dan organisasi. Penggunaan waktu dalam menyelesaikan pekerjaan tetap menjadi perhatian sehingga penyelesaian pekerjaan sesuai dengan target waktu yang sudah ditentukan, karena apabila melebihi target waktu yang sudah ditentukan tentunya berdampak terhadap penyelesaian pekerjaan lainnya. Target biaya juga berpengaruh terhadap kinerja, karena apabila organisasi tidak mampu menyerap anggaran dengan baik tentunya berpengaruh terhadap anggaran yang akan diperoleh pada tahun berikutnya.

\section{KESIMPULAN DAN IMPLIKASI}

\section{Kesimpulan}

Hasil penelitian menunjukkan bahwa efektivitas penilaian kinerja berbasis ekinerja di Pusat Pelatihan Manajemen dan Kepemimpinan Pertanian memperoleh skor rerata sebesar 4,14 termasuk kategori penilaian baik. Dikaitkan dengan empat dimensi penilaian kinerja, maka skor tertinggi berada pada dimensi kualitas yang memperoleh nilai rerata sebesar 4,24 termasuk dalam kategori penilaian sangat baik, sedangkan dimensi biaya memiliki skor rerata terendah sebesar 4,06 walaupun termasuk kategori penilaian baik.

Penilaian kinerja berbasis e-kinerja di Pusat Pelatihan Manajemen dan Kepemimpinan Pertanian berjalan dengan baik dan efektif. Oleh karena, penilaian dilaksanakan dengan obyektif, walaupun masih terdapat penilaian yang dilakukan hanya dengan melihat aktivitas harian yang diinput pegawai melalui aplikasi e-kinerja. Hal tersebut ditunjang oleh kemampuan atasan memberikan penilaian obyektif sesuai dengan aktivitas harian yang mencapai realisasi tiap bulannya. Atasan juga dapat memantau dan melihat capaian realisasi dari tiap pegawai melalui aplikasi e-kinerja. 


\section{Implikasi}

Penelitian efektivitas penilaian kinerja berbasis e-kinerja berimplikasi terhadap hal-hal sebagai berikut:

1) Sistem penilaian kinerja memperhatikan aspek kuantitas, maksudnya jumlah hasil kerja yang dicapai pegawai dalam hitungan bulanan, pejabat penilai menilai berdasarkan hasil kerja atau aktivitas kerja yang dilakukan oleh pegawai tersebut sesuai target yang sudah ditentukan oleh atasan langsung atau pejabat penilainya.

2) Sistem penilaian berdasarkan kualitas, kualitas yang dimaksud adalah capaian kerja pegawai yang sesuai dengan target kerja yang merupakan aktivitas harian masing-masing pegawai yang diinput melalui aplikasi e-kinerja, pegawai harus menempuh target kerja sesuai dengan butir-butir kegiatan sesuai dengan tugas pokoknya.

3) Sistem penilaian kinerja memperhatikan aspek waktu, hal ini dilihat dari target waktu yang dicapai pegawai dalam menyelesaikan target waktu yang sudah ditentukan, pegawai harus menempuh target kerja dengan target waktu berupa bulanan.

4) Sistem penilaian kinerja berdasarkan biaya, hal ini dimaksudkan setiap kegiatan dilaksanakan sesuai dangan target biaya, biaya sesuai dengan jumlah anggaran belanja atau target penerimaan yang ada dalam APBN, apabila anggaran yang digunakan tidak mencapai target yang sudah ditentukan. Apabila target yang digunakan tidak mencapai target, maka anggaran untuk tahun berikutnya akan dikurangi.

\section{DAFTAR PUSTAKA}

\section{Buku}

Mondy, R. (2008). Manajemen Sumber Daya Manusia. Jakarta: Erlangga.

Sugiyono. (2000). Metode Penelitian Bisnis. Bandung: Alfabeta.

\section{Jurnal}

Komara, Eka Putri. (2014). "Pengaruh Penerapan E-Kinerja Dan Penghargaan (Reward) Terhadap Kinerja Aparatur Pengelolaan Keuangan Di Lingkungan Pemerintahan Kota Banda Aceh". Jurnal Magister Akuntansi, 3(4).

\section{Peraturan Perundang-undangan}

Intruksi Presiden Nomor 3 Tahun 2003 tentang Kebijakan dan Strategi Nasional Pengembangan e-Government.

Peraturan Pemerintah Nomor 46 Tahun 2011 tentang Penilaian Prestasi Kerja Pegawai Negeri Sipil (Lembaran Negara Republik Indonesia Tahun 2011 Nomor 121, Tambahan Lembaran Negara Republik Indonesia Nomor 5258).

Peraturan Menteri Pertanian Republik Indonesia Nomor 12 Tahun 2019 tentang Penilaian Kinerja Pegawai Lingkup Kementerian Pertanian.

Undang-Undang Nomor 43 Tahun 1999 tentang Perubahan Atas UndangUndang Nomor 8 Tahun 1974 Tentang Pokok-pokok Kepegawaian (Lembaran Negara Republik Indonesia Tahun 1999 Nomor 169). 